\title{
Traffic Accident Model Reviewed from The Factors of Driving Behaviour of Surabaya-Gempol Toll Road
}

\author{
Dadang Supriyatno $^{1 *}$, Sri Wiwoho Mudjanarko ${ }^{2}$, Hermanto Dwiatmoko ${ }^{3}$ \\ ${ }^{1} J 1$. Ketintang, Ketintang, Kec. Gayungan, \\ Universitas Negeri Surabaya, Surabaya, 60231, INDONESIA \\ ${ }^{2}$ Arief Rachman Hakim 51, \\ Narotama University, Surabaya, 60117, INDONESIA \\ ${ }^{3}$ Meruya Selatan No. 01 Kembangan-Jakarta Barat, \\ Universitas Mercu Buana, 11650, INDONESIA \\ *Corresponding Author
}

DOI: https://doi.org/10.30880/ijie.2020.12.08.027

Received 12 October 2019; Accepted 21 April 2020; Available online 15 September 2020

\begin{abstract}
The development of road capacity is not in line with the development of the population and the increase in the number of vehicles. This has become a classic problem of transportation in the big cities of Indonesia, including in East Java Province. The existence of road capacity in accommodating vehicles must be resolved. One way to accommodate the number of vehicles is through the toll road. But comfortable conditions of the toll road can cause accidents. One factor causing this is the driver's behavior factors, as the toll road is a freeway, they tend to drive carelessly. On the other hand, high planning standards make the difference between toll roads and ordinary highways. Yet barrier-free road does not mean that the traffic accident problem can be resolved properly. This study aims to determine how significant is the influence of driver behavior factor in causing accidents. The methodology is done by analyzing the data using statistical methods. Based on the accident data obtained, a mathematical model with multiple linear regression analysis is made. The model connects the number of traffic accidents on the Surabaya-Gempol toll road with the number of accidents caused by driver factors. The results showed that the factors causing the accident were caused by less anticipated driver factors, carelessness, drowsiness, drunkenness, distance, etcetera. This variable has a significant effect on traffic accidents at SurabayaGempol Toll Road by 54\%.
\end{abstract}

Keywords: Traffic accident, model, driving behaviour, toll road

\section{Introduction}

Indonesia is a country that has the largest population in ASEAN. This population requires adequate transportation infrastructure. Good transportation arrangements require good urban land use as well. The Indonesian government is currently building a connectivity by constructing infrastructures, especially toll roads [15]. Development and financing of toll roads are by involving private parties. Basically, the construction of toll roads is designed to reduce traffic congestion in the city and outside the city. According to Oglesby, as quoted by Santoso (2007), other benefits obtained by the existence of toll roads include factors of large capacity, reducing travel time, more safety, permanently built, reducing operating costs, and reducing noise pollution in the city. Toll roads are only intended for road users who use four-wheeled or more motorized vehicles. 
This scheme does not require much of Indonesia's state budget. High toll development costs are very much in need of the private sector [16]. The road pavement itself consists of rigid and flexible (asphalt) pavement. Toll road pavement uses rigid pavement, more than asphalt pavement. In addition, it can use a combination of pavement and asphalt [3]. Road capacity must be equipped with traffic signs in order to help the driver [1], [2], [23]. Road capacity must be able to accommodate private vehicles and public transport vehicles, especially buses. Toll roads also have a function to connect regions to other regions. Some infrastructures can be accessed via toll roads: toll access [7], [8] [13], [17], airport facilities, trains, ports will develop with the existence of the toll road [11], [12], [14], [19]. The existence of public facilities is increasing, especially parking needs [5], [9], [10], [18], [23].

The use of information technology is needed in completing the development of transportation system also. This is one form of toll road service to access to public places [4], [6]. The importance of toll roads as such must be followed by the safety factors, guaranteeing the journey. As the drivers often neglecting in and causing accidents. Roads that are free of obstacles does not mean that traffic accident problems can be resolved properly. Traffic accidents on toll roads can have more fatal consequences compared to traffic accidents that occur on non-toll roads [20].

According to data from Jasa Marga Surgem (Surabaya-Gempol), a Badan Usaha Milik Negara (BUMN) or Country-owned enterprise that governs toll roads, $65 \%$ of traffic accidents that occurred over the past six years are caused by driver factors. The fact that there are still many drivers unable to understand things that has to be done properly on the toll roads has caused a high level of accidents.

The main cause is the human factor. The driver him or herself, because he or she fails to anticipate things. After that the vehicle, and then the environment, as a sub-factor. Because the one who can think and have feelings are the drivers. If every driver is able to control the behavior during driving in accordance with the conditions of the vehicle, the environment, and him or herself, we can be sure the number of traffic accidents that occur on the toll road can be reduced.

In this case, traffic accidents that occur on toll roads seen from driver factors according to Jasa Marga include less anticipation, negligence, drowsiness, drunkenness, distance of meetings, and others. The relationship between these variables and the number of traffic accidents that occur on the Surabaya-Gempol toll road will form a mathematical model. This study attempts to model the number of accidents on the Surabaya-Gempol toll road with factors causing traffic accidents, that are reviewed based on driver factors. The methodology is used statistically so that mathematical models can be obtained.

\section{Methods}

Definition of accident and criteria for Indonesian government regulation (PP) No. 431993 states that traffic accidents are events on unexpected and unintentional roads involving vehicles that are moving with or without other road users, resulting in human casualties (victims) or property losses. Other errors that are usually not noticed by drivers driving on the highway are, the lack of control of their vehicles regarding whether or not the vehicle is operated on the highway, with the recommended minimum speed.

For toll roads used for traffic in urban areas, the minimum speed is $60 \mathrm{~km} / \mathrm{hour}$, while the recommended minimum speed inter-city traffic is $80 \mathrm{~km} /$ hour (Article 5 of Government Regulation Number 15 of 2005 concerning Toll Roads). Even explicitly according to Article 21 of Law No. 22 of 2009 concerning Road Traffic and Transportation requires a minimum speed of $60 \mathrm{~km} /$ hour.

The Surabaya-Gempol toll road is a $43 \mathrm{~km}$ freeway that crosses three regions, namely Surabaya, Sidoarjo and Pasuruan. The existence of the Lapindo mudflow disaster in Porong-Sidoarjo since 2009 has caused the toll road to be cut-off for $6 \mathrm{~km}$ so that the Surabaya-Gempol toll road that operates to date is $37 \mathrm{~km}$ long. The operation of the Surabaya-Gempol toll road is intended to reduce traffic congestion in the city of Surabaya because vehicles from Surabaya that will pass towards Malang or vice versa do not have to pass through the city centre. In this study, the research location is along the Surabaya-Gempol toll road starting from STA $00+000$ - STA $37+00$.

Toll roads have a higher level of security and comfort services than existing public roads and can service longdistance traffic with high mobility. Lack of attention to this, triggers poor driving behavior, especially on the freeway. In addition, are with various factors inherent in the driver such as physical fitness, mental readiness while driving, fatigue, the influence of liquor, and drugs. The condition of unpreparedness of the driver opens a great opportunity for severe accidents in addition to endangering other road users. Outline of the steps of this study includes (refer Fig. 1 for the flowchart):

a) Determination of research objectives.

b) Conduct relevant literature studies with the aim above.

c) Data collection:

- Data on traffic accident reports include records of events accidents and monthly reports traffic accident.

- Technical data and conditions of the toll road including Average daily traffic data, road geometric, traffic control data.

d) Data processing:

- Data extraction according to needs needed.

- Compile and search through several steps to obtain data adequacy. 
e) Field observations.

f) Analysis and discussion.

g) Conclusions and suggestions.

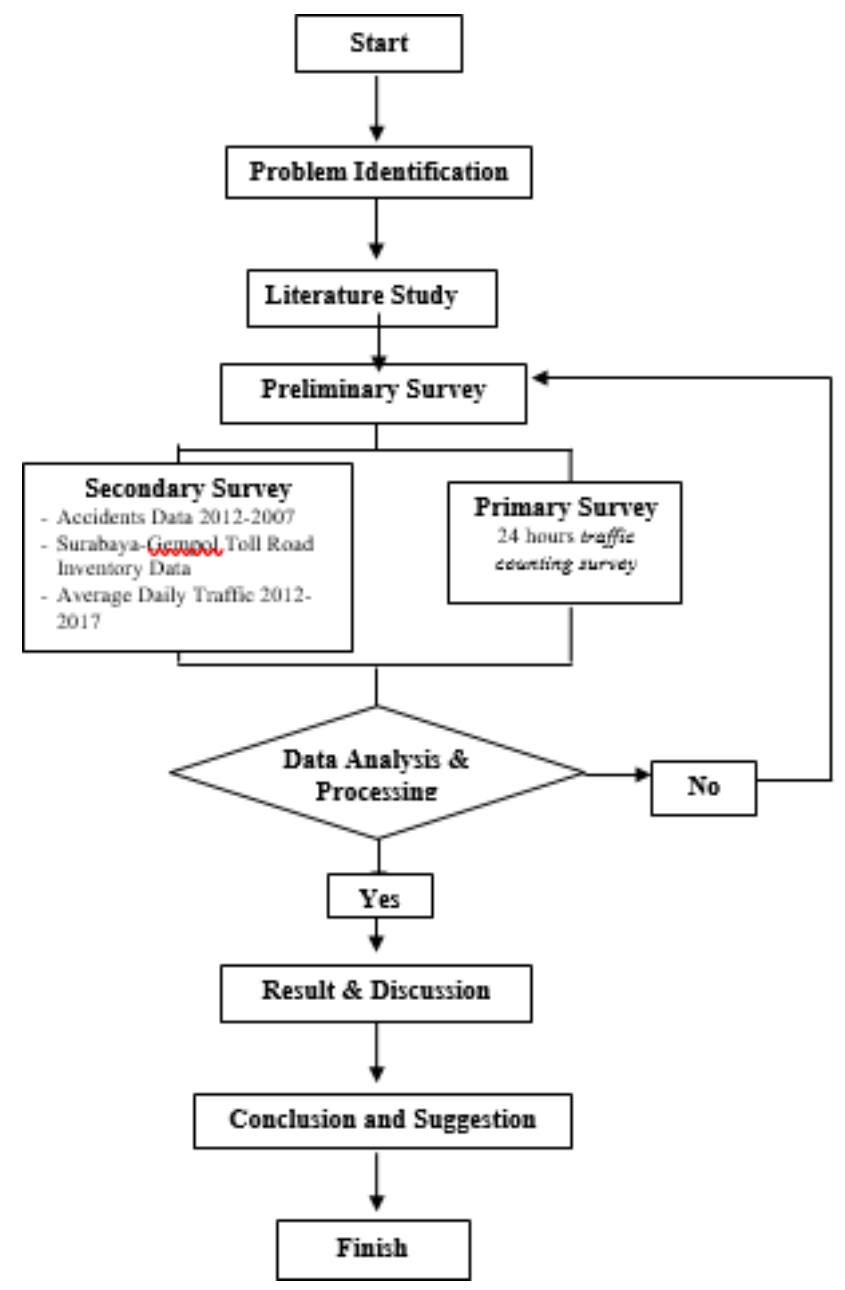

Fig. 1 - Flowchart

\section{Results and Discussion}

The following is a description of the recapitulation of accident rates and traffic accident fatality rates on the Surabaya-Gempol toll road in the last six years (2012-2017).

Table 1 - Recapitulation of accident level and fatality level at Surabaya-Gempol Toll Road (2012-2017)

\begin{tabular}{lllllll}
\hline Description & Year & Year & Year & Year & Year & Year \\
& $\mathbf{2 0 1 2}$ & $\mathbf{2 0 1 3}$ & $\mathbf{2 0 1 4}$ & $\mathbf{2 0 1 5}$ & $\mathbf{2 0 1 6}$ & $\mathbf{2 0 1 7}$ \\
\hline Accidents level & 4,98 & 3,42 & 2,39 & 2,89 & 2,91 & 2,59 \\
Fatality level & 0,91 & 0,56 & 0,53 & 0,51 & 0,33 & 0,59 \\
\hline
\end{tabular}

The data used is for six years ( 72 months). The following are the details of the data that were used to form the accident modeling.

Table 2 - Traffic accident modeling data

\begin{tabular}{cccccccc}
\hline No & $\begin{array}{c}\text { Number of } \\
\text { Accidents (Y) }\end{array}$ & $\begin{array}{c}\text { Less Anticipation } \\
\text { (X1) }\end{array}$ & $\begin{array}{c}\text { Off guard } \\
(\mathbf{X} 2)\end{array}$ & $\begin{array}{c}\text { Sleepy } \\
(\mathbf{X 3 )}\end{array}$ & $\begin{array}{c}\text { Drunk } \\
(\mathbf{X 4 )}\end{array}$ & $\begin{array}{c}\text { Close } \\
\text { Distance (X5) }\end{array}$ & $\begin{array}{c}\text { Others } \\
(\mathbf{X 6})\end{array}$ \\
\hline 1 & 4 & 1 & 0 & 1 & 0 & 0 & 0 \\
2 & 6 & 3 & 0 & 1 & 0 & 0 & 0 \\
\hline
\end{tabular}




\begin{tabular}{|c|c|c|c|c|c|c|c|}
\hline 3 & 6 & 3 & 0 & 1 & 0 & 1 & 0 \\
\hline 4 & 6 & 3 & 0 & 2 & 0 & 0 & 0 \\
\hline 5 & 5 & 1 & 0 & 1 & 0 & 0 & 0 \\
\hline 6 & 5 & 1 & 0 & 2 & 0 & 0 & 0 \\
\hline 7 & 4 & 0 & 0 & 1 & 0 & 0 & 0 \\
\hline 8 & 4 & 0 & 0 & 2 & 0 & 0 & 0 \\
\hline 9 & 7 & 2 & 0 & 4 & 0 & 0 & 0 \\
\hline 10 & 4 & 1 & 1 & 0 & 0 & 0 & 0 \\
\hline 11 & 7 & 2 & 0 & 3 & 0 & 0 & 0 \\
\hline 12 & 3 & 0 & 0 & 1 & 0 & 0 & 1 \\
\hline 13 & 5 & 2 & 0 & 1 & 0 & 1 & 0 \\
\hline 14 & 5 & 3 & 0 & 1 & 0 & 0 & 0 \\
\hline 15 & 3 & 0 & 0 & 1 & 0 & 0 & 0 \\
\hline 16 & 5 & 1 & 0 & 2 & 0 & 1 & 0 \\
\hline 17 & 4 & 1 & 0 & 2 & 0 & 0 & 0 \\
\hline 18 & 4 & 2 & 0 & 1 & 0 & 0 & 0 \\
\hline 19 & 3 & 0 & 1 & 2 & 0 & 0 & 0 \\
\hline 20 & 1 & 0 & 0 & 1 & 0 & 0 & 0 \\
\hline 21 & 2 & 1 & 0 & 1 & 0 & 0 & 0 \\
\hline 22 & 4 & 1 & 0 & 1 & 0 & 0 & 0 \\
\hline 23 & 4 & 0 & 0 & 1 & 0 & 0 & 0 \\
\hline 24 & 5 & 1 & 0 & 1 & 0 & 0 & 0 \\
\hline 25 & 7 & 3 & 1 & 0 & 0 & 1 & 0 \\
\hline 26 & 4 & 0 & 0 & 1 & 0 & 0 & 0 \\
\hline 27 & 3 & 2 & 1 & 0 & 0 & 0 & 0 \\
\hline 28 & 5 & 3 & 0 & 0 & 0 & 0 & 0 \\
\hline 29 & 4 & 1 & 0 & 0 & 0 & 0 & 0 \\
\hline 30 & 6 & 1 & 1 & 0 & 0 & 1 & 0 \\
\hline 31 & 4 & 1 & 0 & 2 & 0 & 0 & 0 \\
\hline 32 & 6 & 1 & 2 & 2 & 0 & 0 & 0 \\
\hline 33 & 6 & 1 & 0 & 2 & 0 & 0 & 0 \\
\hline 34 & 1 & 0 & 0 & 0 & 0 & 0 & 0 \\
\hline 35 & 6 & 2 & 0 & 1 & 1 & 1 & 0 \\
\hline 36 & 7 & 1 & 0 & 2 & 0 & 1 & 0 \\
\hline 37 & 3 & 1 & 0 & 1 & 0 & 0 & 0 \\
\hline 38 & 3 & 1 & 0 & 1 & 0 & 0 & 0 \\
\hline 39 & 6 & 1 & 1 & 2 & 0 & 0 & 1 \\
\hline 40 & 7 & 1 & 1 & 0 & 0 & 0 & 0 \\
\hline 41 & 5 & 2 & 0 & 2 & 0 & 0 & 0 \\
\hline 42 & 6 & 0 & 0 & 3 & 0 & 1 & 0 \\
\hline 43 & 5 & 0 & 1 & 3 & 0 & 1 & 0 \\
\hline 44 & 5 & 1 & 0 & 2 & 0 & 0 & 0 \\
\hline 45 & 5 & 0 & 0 & 2 & 0 & 0 & 0 \\
\hline 46 & 5 & 3 & 0 & 1 & 0 & 0 & 1 \\
\hline 47 & 6 & 1 & 1 & 3 & 0 & 0 & 0 \\
\hline 48 & 5 & 0 & 0 & 3 & 0 & 0 & 0 \\
\hline 49 & 5 & 0 & 0 & 2 & 0 & 0 & 1 \\
\hline 50 & 5 & 1 & 1 & 2 & 0 & 0 & 0 \\
\hline 51 & 5 & 4 & 0 & 1 & 0 & 0 & 0 \\
\hline
\end{tabular}




\begin{tabular}{lcllllll}
\hline 52 & 4 & 2 & 0 & 1 & 0 & 0 & 0 \\
53 & 5 & 1 & 0 & 1 & 0 & 0 & 0 \\
54 & 4 & 2 & 0 & 2 & 0 & 0 & 0 \\
55 & 6 & 1 & 0 & 1 & 0 & 0 & 0 \\
56 & 5 & 2 & 0 & 1 & 0 & 0 & 0 \\
57 & 3 & 0 & 0 & 2 & 0 & 0 & 0 \\
58 & 5 & 3 & 0 & 0 & 0 & 0 & 0 \\
59 & 6 & 1 & 1 & 3 & 0 & 0 & 0 \\
60 & 5 & 1 & 2 & 0 & 0 & 1 & 0 \\
61 & 7 & 4 & 0 & 0 & 0 & 0 & 0 \\
62 & 5 & 3 & 0 & 1 & 0 & 0 & 0 \\
63 & 5 & 4 & 0 & 0 & 0 & 0 & 0 \\
64 & 10 & 4 & 0 & 4 & 0 & 0 & 0 \\
65 & 6 & 3 & 0 & 0 & 0 & 0 & 0 \\
66 & 6 & 3 & 0 & 0 & 0 & 0 & 0 \\
67 & 7 & 3 & 0 & 1 & 0 & 0 & 0 \\
68 & 10 & 2 & 0 & 1 & 0 & 0 & 0 \\
69 & 10 & 2 & 1 & 4 & 0 & 0 & 0 \\
70 & 6 & 1 & 0 & 2 & 1 & 0 & 0 \\
71 & 14 & 1 & 0 & 5 & 0 & 2 & 0 \\
72 & 6 & 1 & 0 & 3 & 0 & 0 & 0 \\
\hline
\end{tabular}

But the increase in fatality rate is something that needs to be looked at again. In this case, the driver's behavior is the dominant option that causes an increase in the fatality rate that occurs on the Surabaya-Gempol toll road. In this case, traffic accidents that occur on the toll road are seen from the driver's factor according to Jasa Marga, including lack of anticipation, carelessness, drowsiness, drunkenness, a close distance accident (spacing), and others. The relationship between these variables with the number of traffic accidents that occur on the Surabaya-Gempol toll road will form a mathematical model. This study tries to model the number of accidents on the Surabaya-Gempol toll road with the factors that cause traffic accidents which are reviewed based on the driver factor.

Fig. 2 shows the factors causing the accident on the Surabaya-Gempol toll road. It can be identified that the accident factor has been obtained data that the driver factor is $65 \%$, vehicle factor $33 \%$, road factor 15 and environmental factor $1 \%$. The driver factor is the highest factor causing traffic accidents, namely 243 accidents from 377 accidents $(65 \%)$.

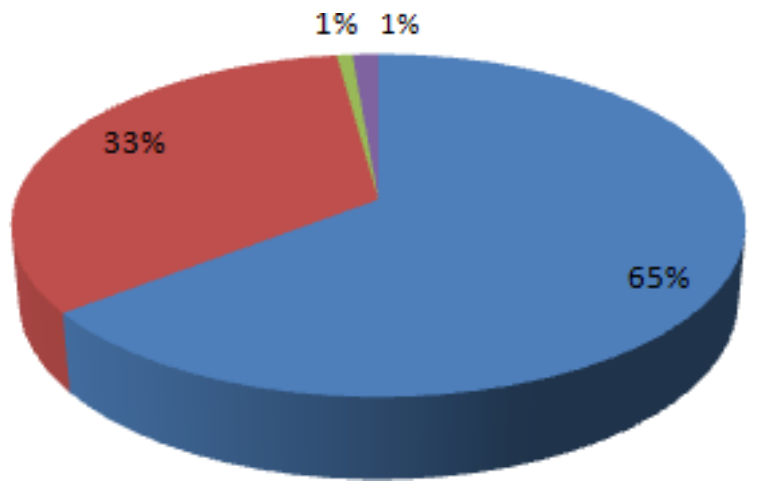

Fig 2 - Traffic accident factors at Surabaya-Gempol toll road

The model of the cause of traffic accidents on the Surabaya-Gempol toll road based on the driver factor consists of seven variables including the dependent variable with the number of traffic accidents and the independent variable is the number of traffic accidents from each driver factor classification, which are the lack of anticipation, carelessness, drowsiness, drunkenness, spacing, etc. The results of data calculations were obtained using computer assistance with the application of the SPSS 16.0 program. The result of multiple linear regression analysis can be seen as classic assumption test and others. 


\subsection{Normality Test}

Fig. 3 shows the normal P-P plot of regression standardized residual. Meanwhile, Table 3 shows that the data follows the direction of the diagonal line so it can be concluded that the data is normally distributed. The KolmogorovSmirnov test also obtained normal distribution results, but in the Asymp column, Sig (2-tailed) stated that the significance level of these variables was less than 0.05 . One of the causes of the lack of significance is the amount of data obtained does not meet the items tested

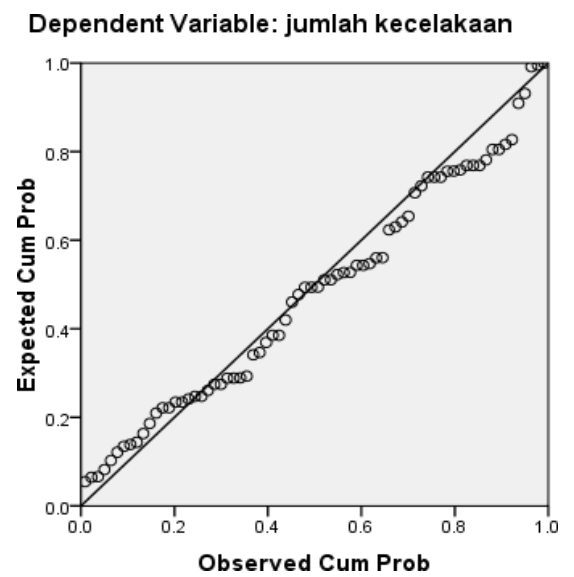

Fig 3. Normal probability plot

Table 3. Normality test

\begin{tabular}{|c|c|c|c|c|c|c|c|c|}
\hline \multicolumn{9}{|c|}{ One-Sample Kolmogorov-Smirnov Test } \\
\hline & & $\begin{array}{c}\text { Number of } \\
\text { accidents }\end{array}$ & $\begin{array}{c}\text { Lack of } \\
\text { anticipation }\end{array}$ & Careless & Sleepy & Drunk & $\begin{array}{l}\text { Meeting } \\
\text { distance }\end{array}$ & Others \\
\hline \multicolumn{2}{|c|}{$\mathrm{N}$} & 72 & 72 & 72 & 72 & 72 & 72 & 72 \\
\hline \multirow{2}{*}{$\begin{array}{l}\text { Normal } \\
\text { Parameters }\end{array}$} & Mean & 5.22 & 1.46 & 0.22 & 1.44 & 0.03 & 0.17 & 0.06 \\
\hline & Std. Deviation & 1.980 & 1.162 & 0.481 & 1.124 & 0.165 & 0.411 & 0.231 \\
\hline \multirow{3}{*}{$\begin{array}{l}\text { Most Extreme } \\
\text { Differences }\end{array}$} & Absolute & 0.194 & 0.264 & 0.483 & 0.237 & 0.539 & 0.505 & 0.540 \\
\hline & Positive & 0.194 & 0.264 & 0.483 & 0.237 & 0.539 & 0.505 & 0.540 \\
\hline & Negative & -0.136 & -0.138 & -0.322 & -.152 & -0.433 & -0.343 & -0.405 \\
\hline \multicolumn{2}{|c|}{ Kolmogorov-Smirnov Z } & 1.650 & 2.244 & 4.102 & 2.011 & 4.572 & 4.282 & 4.579 \\
\hline \multicolumn{2}{|c|}{ Asymp. Sig. (2-tailed) } & .009 & 0.000 & 0.000 & 0.001 & 0.000 & 0.000 & 0.000 \\
\hline
\end{tabular}

\subsection{Autocorrelation Test}

Table 4 shows the Durbin-Watson autocorrelation. In this calculation for $\mathrm{N}=72$ and $\mathrm{k}=6$ based on Durbin Watson's table, the value of $\mathrm{dL}=1.433$ and $\mathrm{dU}=1.801$, while for the value of $\mathrm{DW}$ is 1.515 . The $\mathrm{DW}$ value lies in the area $\mathrm{dL}<\mathrm{d}<\mathrm{dU}(1,443<1,515<1,801)$, so it can be seen that there are no conclusions regarding the presence or absence of autocorrelation in this model.

Table 4. Durbin-Watson autocorrelation

\begin{tabular}{cccccc}
\hline \multicolumn{5}{c}{ Model Summary $^{\mathbf{b}}$} \\
\hline Model & $\mathbf{R}$ & \multicolumn{4}{c}{ R Square Adjusted R Square Std. Error of the Estimate Durbin-Watson } \\
1 & $0.765^{\mathrm{a}}$ & 0.586 & 0.547 & 1.332 & 1.515 \\
\hline
\end{tabular}

Table 5 shows the multikolinearitas test. In the multicollinearity test, it can be seen that the value of the tolerance is more than 0.1 and the value in VIF is less than 10. Therefore, it can be concluded that the values of these variables do not have any symptoms of multicollinearity. 
Tabel 5 - Multicollinearity test

\begin{tabular}{lcc}
\hline \multirow{2}{*}{ Model } & \multicolumn{2}{c}{ Collinearity } \\
& Tolerance & VIF \\
\hline Constant & - & - \\
Lack of anticipation & 0.924 & 1.083 \\
Careless & 0.942 & 1.062 \\
Sleepy & 0.920 & 1.087 \\
Drunk & 0.969 & 1.032 \\
Meeting distance & 0.910 & 1.099 \\
Others & 0.979 & 1.021 \\
\hline
\end{tabular}

Table 6 shows the data of heteroskedastisitas test. The statistical value of all explanatory variables tested with the dependent variable of the abresid value based on the probability that there is no statistically significant (probability $>$ 0.05). Therefore, it can be concluded that no symptoms of heteroscedasticity are presence in this model.

Table 6. Heteroskedastisitas test

\begin{tabular}{|c|c|c|c|c|c|c|}
\hline \multicolumn{7}{|c|}{ Coefficients $^{\mathrm{a}}$} \\
\hline & \multirow{2}{*}{ Model } & \multicolumn{2}{|c|}{ Unstandardized Coefficients } & \multirow{2}{*}{$\begin{array}{c}\text { Standardized } \\
\text { Coefficients } \\
\text { Beta } \\
\end{array}$} & \multirow{2}{*}{$\mathbf{t}$} & \multirow{2}{*}{ Sig. } \\
\hline & & B & Std. Error & & & \\
\hline \multirow{7}{*}{1} & Constant & .965 & .246 & & 3.924 & .000 \\
\hline & Lack of anticipation & .004 & .091 & .005 & .041 & .967 \\
\hline & Careless & -.101 & .218 & -.057 & -.460 & .647 \\
\hline & Sleepy & -.030 & .095 & -.039 & -.312 & .756 \\
\hline & Drunk & -.413 & .626 & -.081 & -.659 & .512 \\
\hline & Meeting distance & .426 & .260 & .207 & 1.637 & .107 \\
\hline & Others & -.296 & .447 & -.081 & -.663 & .509 \\
\hline
\end{tabular}

a. Dependent variable abresid

Table 7 shows the correlation matrix consists of number of accidents, lack of anticipation, careless, sleepy, drunk, meeting distance and others. Based on the correlation matrix and judging from the magnitude of significance, it can be decided as follows:

- The relationship between the number of accidents and the less anticipated causal factor of the correlation coefficient is 0.371 and the significance value is 0.001 less than 0.005 which means there is a correlation.

- The relationship between the number of accidents and the care-less causative factor of the correlation coefficient is 0.095 and the significance value is 0.213 greater than 0.005 which means there is no correlation.

- The relationship between the number of accidents and the factor causing sleepy correlation coefficient is 0.474 . And the significance value is 0.000 less than 0.005 , which means there is a correlation between the factors.

- The relationship between the number of accidents and the cause of drunkenness correlation coefficient is 0.067 and the significance value is 0.288 greater than 0.005 , which means there is no correlation between the factors.

- The relationship between the number of accidents and the cause distance factor of the correlation coefficient is 0.404 and the significance value is 0.000 less than 0.005 which means there is a correlation between the factors.

- The relationship between the number of accidents with the causal factor etc the correlation coefficient is -0.58 and the significance value is 0.314 greater than 0.005 which means there is no correlation between the factors.

Table 7 - Correlation matrix

\begin{tabular}{llccccccc}
\hline \multicolumn{7}{c}{ Correlations } \\
\hline & $\begin{array}{c}\text { Number of } \\
\text { accidents }\end{array}$ & $\begin{array}{c}\text { Lack of } \\
\text { anticipation }\end{array}$ & Careless & Sleepy & Drunk & $\begin{array}{c}\text { Meeting } \\
\text { distance }\end{array}$ & Others \\
\hline \multirow{2}{*}{$\begin{array}{l}\text { Pearson } \\
\text { Correlation }\end{array}$} & $\begin{array}{l}\text { Number of } \\
\text { accidents }\end{array}$ & 1.000 & 0.371 & 0.095 & 0.474 & 0.067 & 0.404 & -0.058 \\
\cline { 2 - 9 } & $\begin{array}{l}\text { Lack of } \\
\text { anticipation } \\
\text { Careless }\end{array}$ & 0.371 & 1.000 & -0.134 & -0.223 & 0.006 & $0-.044$ & -0.096 \\
& 0.095 & -0.134 & 1.000 & -0.003 & -0.079 & 0.166 & 0.014 \\
\hline
\end{tabular}




\begin{tabular}{|c|c|c|c|c|c|c|c|c|}
\hline & Sleepy & 0.474 & -0.223 & -0.003 & 1.000 & 0.008 & 0.173 & 0.012 \\
\hline & Drunk & 0.067 & 0.006 & -0.079 & 0.008 & 1.000 & 0.138 & -0.041 \\
\hline & Meeting distance & 0.404 & -0.044 & 0.166 & 0.173 & 0.138 & 1.000 & -0.099 \\
\hline & Others & -0.058 & -0.096 & 0.014 & 0.012 & -0.041 & -0.099 & 1.000 \\
\hline \multirow{7}{*}{$\begin{array}{l}\text { Sig. } \\
\text { (1-tailed) }\end{array}$} & $\begin{array}{l}\text { Number of } \\
\text { accidents }\end{array}$ & - & .001 & 0.213 & 0.000 & 0.288 & 0.000 & 0.314 \\
\hline & $\begin{array}{l}\text { Lack of } \\
\text { anticipation }\end{array}$ & 0.001 & - & 0.130 & 0.030 & 0.480 & 0.356 & 0.210 \\
\hline & Careless & 0.213 & 0.130 & - & 0.490 & 0.256 & 0.082 & 0.453 \\
\hline & Sleepy & 0.000 & 0.030 & 0.490 & - & 0.472 & 0.073 & 0.460 \\
\hline & Drunk & 0.288 & 0.480 & 0.256 & 0.472 & - & 0.124 & 0.366 \\
\hline & Meeting distance & 0.000 & 0.356 & 0.082 & 0.073 & 0.124 & - & 0.204 \\
\hline & Others & 0.314 & 0.210 & 0.453 & 0.460 & 0.366 & 0.204 & - \\
\hline \multirow{7}{*}{$\mathrm{N}$} & $\begin{array}{l}\text { Number of } \\
\text { accidents }\end{array}$ & 72 & 72 & 72 & 72 & 72 & 72 & 72 \\
\hline & $\begin{array}{l}\text { Lack of } \\
\text { anticipation }\end{array}$ & 72 & 72 & 72 & 72 & 72 & 72 & 72 \\
\hline & Careless & 72 & 72 & 72 & 72 & 72 & 72 & 72 \\
\hline & Sleepy & 72 & 72 & 72 & 72 & 72 & 72 & 72 \\
\hline & Drunk & 72 & 72 & 72 & 72 & 72 & 72 & 72 \\
\hline & Meeting distance & 72 & 72 & 72 & 72 & 72 & 72 & 72 \\
\hline & Others & 72 & 72 & 72 & 72 & 72 & 72 & 72 \\
\hline
\end{tabular}

\subsection{Analysis of The Effect of Variables (Y on X)}

F test was used to determine the effect of the overall independent variable on the dependent variable. Table 8 presents a simultaneous or overall analysis of the effect variance based on the F test.

Table 8 - F test

\begin{tabular}{ccccccc}
\hline \multicolumn{7}{c}{ ANOVA $^{\mathbf{b}}$} \\
\hline \multirow{2}{*}{ Model } & Sum of Squares & df & $\begin{array}{c}\text { Mean } \\
\text { Square }\end{array}$ & F & Sig. \\
\hline \multirow{2}{*}{1} & Regression & 163.059 & 6 & 27.176 & 15.309 & $0.000 \mathrm{a}$ \\
& Residual & 115.386 & 65 & 1.775 & & \\
& Total & 278.444 & 71 & & & \\
\hline
\end{tabular}

Based on the probability value (significance) of 0,000 less than 0.05 , the conclusion is that the factors causing less anticipation, careless, sleepy, meeting distance, drunk, and etc simultaneously affect the number of accidents of traffic on the Surabaya-Gempol toll road. On the other hand, T test was used to determine the effect of partially independent variables on the dependent variable. The T test analysis can be referred in Table 9. Based on the probability value, it can be found that:

- b1 (less anticipation): A probability of $0.000<0.05$, less anticipation factor affecting the number of accidents of traffic.

- b2 (careless): A probability of $0.151>0.05$ carelessness does not affect the number of accidents of traffic.

- b3 (sleepy): Probability is $0.000<0.05$, sleepiness factor affects the number of accidents of traffic.

- b4 (drunk): Probability $0.751>0.05$, drunkenness factor does not affect the number of accidents of traffic.

- b5 (meeting distance): Probability of $0,000<0,05$, the distance or spacing affects the number of accidents of traffic.

- b6 (other): Probability: $0.844>0.05$ some other factors do not significantly affect the number of accidents of traffic. 
Table 9 - T test

\begin{tabular}{lcc}
\hline \multicolumn{1}{c}{ Model } & t & Sig. \\
\hline Constant & 5.744 & 0.000 \\
Lack of anticipation & 6.277 & 0.000 \\
Careless & 1.418 & 0.161 \\
Sleepy & 6.435 & 0.000 \\
Drunk & 0.318 & 0.751 \\
Meeting distance & 3.739 & 0.000 \\
Other & 0.197 & 0.844 \\
\hline
\end{tabular}

Therefore, it is known that the variable lack of anticipation, sleepy and meeting distance has a partial effect on the number of accidents. While the variables careless, drunk and other have no partial effect. Table 10 shows the analysis of the determination coefficient. Analysis of the coefficient of determination (R2) is used to determine the percentage of the contribution of the influence of independent variables simultaneously on the dependent variable.

Table 10 - Analysis of the determination coefficient

\begin{tabular}{cccccc}
\hline \multicolumn{5}{c}{ Model Summary $^{\mathbf{b}}$} \\
\hline Model & R & \multicolumn{4}{c}{ R Square Adjusted R Square Std. Error of the Estimate Durbin-Watson } \\
\hline 1 & $0.765 \mathrm{a}$ & 0.586 & 0.547 & 1.332 & 1.515 \\
\hline
\end{tabular}

From Table 10, it can be seen that the value of R2 (Adjusted R Square) is 0.547 . So, the contribution of the influence of the causes of accidents caused by the driver to the number of accidents is $54 \%$ while the remaining $46 \%$ is influenced by other factors including vehicles, roads and the environment. It should be emphasized here that the results of the data calculation were obtained using computer assistance with the application of the SPSS 18.0 program.

The model that was found above did not escape from several stages of testing and the best model was chosen which was then proposed as a model of the accident on the Surabaya-Gempol toll road in terms of the driving factor. The model is as follows:

$$
\mathrm{Y}=2.189+0.889 \mathrm{X} 1+0.480 \mathrm{X} 2+0.944 \mathrm{X} 3+0.309 \mathrm{X} 4+1.507 \mathrm{X} 5+0.137 \mathrm{X} 6
$$

where: $\mathrm{Y}=$ Number of accidents of traffic by the driver, $\mathrm{X} 1=$ Number of accidents caused by lack of anticipation, $\mathrm{X} 2$ $=$ Number of accidents caused by careless factors, X3 = Number of accidents caused by sleepy factors, X4 = Number of accidents caused by the drunk factor, X $5=$ Number of accidents caused by the meeting distance factor, X6 = Number of accidents caused by other factors.

\section{Conclusion}

Based on the analysis of the determination of the factors causing the accident caused by the driver to the number of accidents, is equal to $54 \%$. While the remaining $46 \%$ is influenced by other factors, including vehicles, roads and the environment. The accident model on the Surabaya-Gempol toll road is depicted in Equation (1) that has relation of number of accidents with driver's factors.

\section{References}

[1] Supriyatno, D., Sulistio, H., Djakfar, L. \& Wicaksono, A. (2012). Permodelan kebutuhan transportasi massal guided busway menggunakan structural equation modeling. Jurnal Transportasi, 12, 1-10.

[2] Supriyatno, D. \& Widayanti, A. (2010). Kinerja layanan bis Kota di Kota Surabaya. Jurnal Transportasi, $10,1-10$.

[3] Prasetijo, J., Pour M. H. \& Ghadiri S. M. R. (2011). Capacity of unsignalized intersections under mixed traffic conditions. Procedia Social and Behavioral Sciences, 16, 676-685.

[4] Prasetijo, J. \& Musa, W. Z. (2016). Modeling zero-inflated regression of road accidents at Johor Federal Road F001. MATEC Web of Conferences, 47, 03001.

[5] Prasetijo, J. \& Zainal, W. Z. (2016). Development of continuous speed profile using GPS at Johor Federal Road F0050. MATEC Web of Conferences, 47, 03001.

[6] Hosseinpour, M., Yahaya, A. S., Ghadiri, S. M. \& Prasetijo, J. (2013). Application of adaptive neuro-fuzzy inference system for road accident prediction. KSCE Journal of Civil Engineering, 17, 1761-1772. 
[7] Dwiatmoko, H. (2011). Program Strategis Peningkatan Keselamatan Perkeretaapian. Jakarta: Direktorat Jenderal Perkeretaapian.

[8] Hermanto Dwiatmoko (2018). Peran perkeretaapian dalam menunjang sistem logistik nasional. Jurnal Transportasi, 18, 87-96.

[9] Saputra, B., Winardi, S., Mudjanarko, S. W. \& Inayati, I. (2012). Identitas digital kendaraan bermotor dengan chip wemos untuk solusi program plat nomor genap ganjil. Proc. of Seminar National Ilmu Terapan, Surabaya, Indonesia.

[10] Limantara, A. D., Purnomo, Y. C. S. \& Mudjanarko, S. W. (2017). Pemodelan sistem pelacakan lot parkir kosong berbasis sensor ultrasonic dan internet of things (IoT) pada lahan parkir diluar jalan. Prosiding Semnastek, 10, 110.

[11] Sholikhin, R., \& Mudjanarko, S. W. (2017). Analisis karakteristik parkir di satuan ruang parkir Pasar Larangan Sidoarjo. Teknika: Engineering and Sains Journal, 1, 145-150.

[12] Mudjanarko, S. W., Purworusmiardi, T. \& Parasian, S. (2015). Parking usage model with simulation program in Surabaya City. Proc. of Narotama International Conference of Civil Engineering, Surabaya, Indonesia.

[13] Sudarso, S., Moetriono, H., Mudjanarko, S. W. \& Oetomo, W. (2018). Crossing feasibility study between Sea freight vehicles port-port of sheet anchor situbondo lombok.we. Inscientech: Journal of Industrial, Science and Technology, 1, 14-27.

[14] Kartika, A. A. G., Mochtar, I. B. \& Widyastuti, H. (2017). Konsep pemodelan durasi dan volume parkir untuk berbagai tata guna lahan di Kota Surabaya. IPTEK Journal of Proceedings Series, 3, 1-10.

[15] Kurniawan, F., Mudjanarko, S. W. \& Ogunlana, S. (2015). Best practice for financial models of PPP projects. Procedia Engineering, 125, 124-132.

[16] Wiwoho, M. S., Machicky, M. \& Nawir, R. (2017). Bamboo waste as part of the aggregate pavement the way green infrastructure in the future. MATEC Web of Conferences, 138, 03013.

[17] Ikhwan Setiawan, M., Dhaniarti, I., Hasyim, C., Atamaja, W. M. T., Utomo, W. M. \& Sugeng, S. (2018). Correlations analysis of airport sustainability and local government budget. International Journal of Integrated Engineering, 10, 1-10.

[18] Slamet, W., Made, K., Tubagus, P., Agus, S. \& Wiwoho, M. S. (2017). internet of things (IoT) as green city economic development smart transportation system. MATEC Web of Conferences, 138, 07015.

[19] Yulmida, D. A., Mudjanarko, S. W., Setiawan, M. I. \& Limantara, A. D. (2017). analisis kinerja parkir sepanjang jalan Walikota Mustajab Surabaya. UKaRsT: Jurnal Online Universitas Kadiri Kediri, 1, 39-46.

[20] JDDC Online Magazine (2011). 15 Mitos dan Fakta Mengemudi Di Jalan Tol. Retrived on 20 January 2012 from http://www.jjdc-online.com.

[21] Sugiyono (2010). Metode Penelitian Pendidikan Pendekatan Kuantitatif, Kualitatif dan R\&D. Bandung: Alfabeta.

[22] Tamin, O. Z. (2008). Perencanaan, Pemodelan dan Rekayasa Transportasi. Bandung: ITB

[23] Muhtadi, A., Wasono, S. B., Artaya, I. P. \& Mudjanarko, S. W. (2012). Evaluasi pelayanan bus dan MPU Kota Surabaya untuk menunjang sistem transportasi berkelanjutan. Proc. of Konferensi National Pascasarjana Teknik Sipil ITB, Bandung, Indonesia. 